\author{
TAKÁCS JUdiT ${ }^{1}$ - RAÁTz JUdiT ${ }^{2,3}$ \\ ${ }^{1}$ Eszterházy Károly Egyetem \\ ${ }^{2}$ Eötvös Loránd Tudományegyetem; \\ ${ }^{3} N y e l v t u d o m a ́ n y i$ Intézet \\ takacs.judit@uni-eszterhazy.hu \\ raatz.judit@btk.elte.hu
}

\title{
NÉVTAN ÉS DRÁMAPEDAGÓGIA: HOGYAN TANÍTSUNK NÉVTANI ISMERETEKET?
}

\author{
„[...] drámajátékkal az iskolai oktató-nevelő \\ munka jellegében és minőségében újítható meg” \\ (Eck 2016: 93)
}

\section{Bevezetés}

A tulajdonnevekkel kapcsolatos ismeretek oktatása mind az általános, mind pedig a középiskolákban sajátos helyzetben van: ez a téma elsősorban az anyanyelvórák részeként, ám indirekt módon jelenik meg, s bár a tananyaghoz kapcsolódóan számos helyen megjelen(het)nek a tulajdonnevek, e téma megismertetésére a tanmenetekben nincs elkülönítve óra.

Tanulmányunkban a hangsúlyt arra helyezzük, hogy bemutassuk, hogyan segítik a drámapedagógia módszerei az anyanyelvórán a tulajdonnevekkel kapcsolatos ismeretek átadását, majd az órák menetébe könnyen beilleszthető gyakorlatokat közlünk, végül pedig egy foglalkozástervet mutatunk be. A gyakorlatok a tanulmány szövegébe illesztve, a tanítási dráma terve pedig a tanulmány végén, mellékletben szerepel.

\section{A névtan tantervbe emeléséről}

Kecskés Judit (2018: 13) utal rá, hogy „azok a kutatások (Raátz 1994; Liszka 1997; Fercsik 1999; Gelegonyáné Katona 2015; F. Láncz 2016; Zántó 2018), amelyek rávilágítanak arra, hogy az általános és középiskolás diákok onomasztikai tájékozottsága mennyire hiányos, szükségessé, az új nemzeti alaptanterv tervezési folyamata pedig lehetővé teheti számunkra a névtan újrapozicionálását a közoktatásban”. Bár tapasztalataink szerint mind az akarat, mind pedig a lehetőség megvan a tulajdonnevek alaposabb megismertetésére, az onomasztikai ismeretek és a tulajdonnevekhez füződő, indirekt módon megjelenő tudnivalók tantárgyi integrációja ma is csupán a neveknek a nyelvtanórák egyes témaköreihez való illesztését, esetleg az egyes névtípusoknak a nyelvtani feladatokban példaanyagként való

1 A kutatást az EFOP-3.6.1-16-2016-00001 „Kutatási kapacitások és szolgáltatások komplex fejlesztése az Eszterházy Károly Egyetemen" című projekt támogatta. 
szerepeltetését jelenti (ld. pl. Hoffmann 1994; Raátz 1994, 1995, 2003; Fercsik-Raátz 1995, 1996; Liszka 1997; Erdélyi 2003; Vörös 2015; F. Láncz 2016).

A tulajdonnévvel kapcsolatos ismeretek átadásának legfőbb terét az anyanyelvóra nyújtja, amikor is számos témakör kapcsán szóba hozhatók (pl. a névhangulattal kapcsolatban a stilisztika tanítása során, helyesírásuk oktatásakor, jelentéstanból a tulajdonnevek jelentése és közszóvá válása kapcsán, s akár a nyelvi változásokat is bemutathatjuk kifejezetten a személy- vagy helynevekhez kötődően), ám úgy tűnik, maga a (hagyományosan) frontális, az ismereteket az egyes tárgyakhoz kötő módszer nem megfelelő a tulajdonnévnek, ennek a tipikusan interdiszciplináris jelenségnek a megközelítésére. Ebben nyújt a drámapedagógia oly módon segítséget, hogy a tantárgyi keretek fellazításával egyszerre képes a komplex ismeretátadásra és a kompetenciafejlesztésre.

\section{Drámapedagógiai módszerek alkalmazásának előnyei a névtanoktatás során}

\subsection{A tantárgyi ismeretek átadása drámapedagógiai módszerekkel}

A dráma meghatározását Kaposi Lászlótól (2008: 2) idézzük: „A dráma olyan csoportos játéktevékenység, amelynek során képzeletbeli (fiktív) világot építenek fel, ebbe a képzeletbeli világba a résztvevők szereplőként vonódnak be, a fiktív világon belül valós problémákkal találkoznak, s ebből valós tudásra és tapasztalásra tesznek szert." Igen lényeges tehát az életszerűség: a dráma során a valószerü helyzetek létrehozásán és az abból leszűrhető tapasztalaton van a hangsúly. „Arra törekszem - írja Szauder Erik (1994: 130) -, hogy az osztály megtanuljon döntéseket hozni, problémát látni, megérteni a döntések következményeit, illetve a döntések következtében rájuk háruló újabb és újabb elvárásokat" (idézi Novák 2016: 44-45).

A drámapedagógia módszereinek iskolai körülmények között való alkalmazása nem elözmények nélküli: elemeit többek között a Waldorf- és a Jenaplan-pedagógia is használja, s bár elsősorban az irodalom- (vö. pl. Tölgyessy 2009; Eck 2015) és a történelemoktatás (Bacskay-Knausz 2001; Szajkó 2008) során használatos, e módszerek eredményességét az anyanyelv- és korai idegennyelv-tanítás, az ének-zene, sőt a matematika és az informatikaoktatás kapcsán is kiemelik (Eck 2016: 102-106). Bár a dráma bevonásának lehetősége széles körű, általánosságban mégis így ír róla Novák Géza Máté (2016: 44): „A hazai oktatási gyakorlat még mindig nem aknázza ki kellően a dráma problémaközpontú tanulást segítő eljárásait, nem fordít elegendő figyelmet a drámapedagógia tanuláselméleti alapjaira. A napi pedagógiai praxis mellett számos hazai és nemzetközi projekt eredménye igazolja, hogy drámával hatékonyabban közvetíthetünk tudásanyagot, tantárgyi tartalmakat, oldhatunk meg iskolai konfliktusokat. A pedagógiai alkalmazások sikerei egyrészt a drámatanári kompetenciákon, másrészt a stratégiák, a munkamódok és a dramatikus munkaformák helyes megválasztásán múlnak.” 
A drámapedagógia céljai összecsengenek a nemzeti alaptanterv kívánalmaival: a cselekvő, élményközpontú tanulást helyezik előtérbe és változatos, sokszínű tevékenységformákon alapulnak. A névtani ismeretek - a terület interdiszciplináris jellegénél fogva - különösen alkalmasak a dráma módszereivel való megközelítésre, hiszen ezáltal megszüntethető a téma oktatásának indirekt jellege, szétaprózottsága, és lehetőség van általa a kompetenciák fejlesztésének azon módjára, mely „több kompetencia egymásba fonódására” épül újra csak összhangban a nemzeti alaptanterv által elvártakkal (Kecskés 2018: 14).

A jól összeállított drámapedagógiai módszereken alapuló névtani foglalkozások során minden hagyományos eszközzel átadott neveket érintő ismeret megjelenhet: a gyakorlatok és foglalkozások során a diákok megismerik a tulajdonnevek legfőbb fajtáit, érintik az egyes névtípusok helyesírásával kapcsolatos tudnivalókat, szóba kerülhetnek tulajdonnevekkel kapcsolatos kommunikációs, esetleg stilisztikai és pragmatikai ismeretek.

Nagy előnye e módszer bevonásának, hogy általa ráébreszthetjük a diákokat arra, hogy az egyes tantárgyakhoz kapcsolódó ismereteik összefüggenek egymással és szervesen kötődnek mindennapi életükhöz is. Az osztálytermi dráma ugyanis „a tudást szociális közegben vizsgálja, valós vagy fiktív szociális helyzetek köré szerveződve felfedezik, és vizsgálat tárgyává teszik a tanulók által elsajátítandó tárgyi ismereteket, fogalmakat és készségeket" (Szauder 1996, idézi Novák 2016: 45). Emiatt egy-egy drámafoglalkozás névadási aktusai és névhasználata alkalmával a diákok valószerủ helyzetekbe kerülnek: megtapasztalhatják névkompetenciájukat (azt a képességet, hogy képesek felismerni, teremteni vagy a szituációnak, célnak és megnevezettnek megfelelő nevet alkalmazni), felismerhetik környezetük jellemző tulajdonnévtípusait (pl. család-, kereszt-, ragadvány-, intézmény- vagy márkaneveit), azok prototipikus vagy ritkább névegyedeit, a nevek stilisztikai jellemzőit.

Ezeken túl azonban olyan fogalmak és ismeretek is megélhetővé, kézzelfoghatóvá válnak a dráma segítségével, melyeket nemcsak a hagyományos, frontális oktatási módszerekkel, de kiscsoportos vagy kooperatív munkán alapuló technikákkal is nehezen tudunk átadhatóvá tenni. A foglalkozás során a diákok egy névközösséggé, azaz sajátos szabályok szerint működő névhasználói csoporttá válnak, és a névadási aktusok során ráébrednek az analógia és a névmodellek mủködésére. Tudatosulhat továbbá bennük a hasonló elemek osztályozásának módja, azaz a kategorizáció működése, ráébredhetnek a sztereotip névhasználat és a névsztereotípiák hátterére, illetve a névadás és névválasztás szociális és kulturális meghatározottságára.

Lényeges, hogy a dráma szellemében a diákok ezeket a jelenségeket megtapasztalják, megéljék, és ennek révén tanulják meg, ne pedig újabb, tanórán elsajátítandó fogalomként ismertessük meg velük. Fontos ezért hangsúlyozni, hogy a foglalkozást vezető tanár feladata a rámutatás ezekre a jelenségre, és nem pedig a definíciószerủ meghatározásuk.

\subsection{A drámafoglalkozások készség- és személyiségfejlesztő hatása}

A tantárgyi ismeretek átadásán túl lényeges a drámafoglalkozások (a diszciplináris ismeretek átadásával egyforma súlyúnak tartott) készség- és személyiségfejlesztő hatását is 
kiemelni. E jellegzetességük miatt a drámafoglalkozások (s köztük a névtan tanítására is alkalmas drámapedagógiai gyakorlatok is) sok esetben mutatnak átfedést a kommunikációs készségfejlesztést célzó feladatokkal, hiszen céljuk részben azonos.

A hasonlóság azon a téren is megjelenik, hogy mindkettő sok esetben jár(hat) a hagyományos óravezetés (órakeretek) felbomlásával, átalakulásával (Fábián-Singer 2009). Egy komplex drámafoglalkozás megtervezéséhez és levezetéséhez ugyanis a szaktudáson és gyakorlaton kívül a hagyományos módszerekhez képest több idő is kell. A tanítási dráma például általában kétszer 45 , a szakértői pedig optimális esetben négyszer 45 percet kíván, s ez messze túlmutat azokon a lehetőségeken, amit (bár több témakörhöz is kapcsolva) lehetővé tesz a kerettanterv (vö. Kecskés 2018: 14-15).

A kommunikációs készségfejlesztést célzó feladatok tanórai lehetőségeit Fábián Györgyi és Singer Péter (2009) az alábbiakban rendszerezte: a) kommunikációs helyzetek alakítása, b) a kommunikációs önismeret javítása, c) kommunikációs stratégiák, d) beszédfejlesztés, e) extralingvisztikai eszközök használata, f) a formalizált kommunikáció fejlesztése, g) a mediális kommunikáció, h) a célkategóriák megfelelő alakítása. A felsorolt lehetőségek mindegyike megjelenhet a drámafoglalkozás során is, ezért a foglalkozás a tantárgyi ismeretek átadásán túl egyben a kompetenciafejlesztés hatékony eszköze is lehet. A tanulói kommunikáció dráma nyújtotta fejlesztési lehetőségeit Raátz Judit (2019) foglalta részletesen össze, s nyújtott példát a különböző fejlesztési célú gyakorlatokra.

A dráma nagy előnye azonban a hagyományos, kommunikációs készségek fejlesztését célzó módszerekkel szemben, hogy segítségével elsősorban a kommunikatív kompetencia (ld. Szőke-Milinte 2012; H. Tomesz 2018) hagyományos módszerekkel nehezen elérhető komponenseinek terén mutatkozik változás. Elsősorban a diákok énképe, motivációi, szociális készségei (szándék, figyelem, részvétel, empátia, attitűd, együttműködési és problémamegoldó készség) (vö. Spencer-McClelland-Spencer 1994; Varga-GöncziPintér 2004) terén érhető el a foglalkozások során jelentős fejlődés.

A drámának erre a szociális és társas készségek terén megnyilvánuló fejlesztő hatására Eck Júlia is utalt (2016: 93), mikor felidézte a nemzetközi DICE-projekt (Drama Improves Lisbon Key Competences in Education) eredményeit. A dráma hatását a lisszaboni nyolc kulcskompetencia közül öt (anyanyelvi kommunikáció; a tanulás tanulása; személyközi, interkulturális és szociális kompetenciák, állampolgári kompetencia; vállalkozói kompetencia, kulturális kifejezőkészség) esetében vizsgálták, s a kutatás bebizonyította, hogy a dráma objektíven mérhető, 22 pontban összefoglalható, szignifikáns fejlesztő hatást gyakorol a vizsgált kulcskompetenciákra (DICE 2010: 37-53). Azt mondhatjuk tehát, hogy a névtani témájú drámafoglalkozások során nemcsak a tantárgyi ismeretek átadására, hanem a személyiségfejlesztésre is komplexebb lehetőségek nyílnak, mint a hagyományos módszerekkel vezetett órák során. 


\section{Névtani témájú gyakorlatok és foglalkozásterv}

A dramatikus tevékenységeket Takács Gábor (2008: 32) Gavin Bolton osztályozása alapján a következőképpen sorolta fel: a) gyakorlatok, b) dramatikus játékok, c) színházi forma, d) tanítási (komplex) dráma, e) szakértői dráma, f) színházi nevelési program. Az alábbiakban a névtani ismereteket fókuszba állító gyakorlatokra, illetve tanítási drámára mutatunk példát.

\subsection{Gyakorlatok}

Bár a dráma fejlesztő hatása jobban érvényesül a komplex foglalkozások során, a tanórákon jó megoldást jelent a rövidebb időigényű gyakorlatok bevonása, melyek egy-egy (nevekhez is kapcsolható) tananyagrész felvezetéseként szolgálhatnak. Mindig szerepel valamilyen tevékenységet meghatározó instrukció bennük, és egyértelmű szabályok kötik a résztvevőket. A formájuk többször ismételhető, a tartalmi rész nem. Előnyük, hogy rövid idő alatt lezárhatók és céljuk erősen kapcsolható a feldolgozandó tananyagrészhez (Takács 2008: 33).

A gyakorlatok közül elsősorban a helyzetgyakorlatok kapcsolhatók erősen a névtanhoz, a szabályjátékok föleg a csoport ráhangolásakor, az órák felvezetésekor hasznosak. Ez utóbbiak közül sok - ahogy Takács Gábor is megjegyzi (2008: 32) - „közkincs”, azaz egymásnak adják tovább a tanárok, azonban számos drámajátékokból összeállított, nyomtatott formában is elérhető kiadvány is létezik már (közülük csak a leggyakrabban használtakat kiemelve: Kaposi 1993; Gabnai 2008; Eck 2015; Pándiné 2017). Ezek gyakorlatai jórészt kiemelt kompetenciák fejlesztését célozzák meg, vagy egy-egy tantárgyhoz kötődnek, de olyan, amely kifejezetten a nyelvtanórákhoz kapcsolható lenne $s$ a tulajdonneveket állítaná a fókuszba, tudomásunk szerint még nem készült. A tanároknak ezért - amennyiben a tulajdonneveket drámás gyakorlatok segítségével kívánják tanítani -, a meglévők alapján tudnak inspirálódni, ám azokat gyakran át kell alakítaniuk, ki kell egészíteniük, s ez sok esetben idő híján akadályozza a munkát. Az alábbi feladatokkal ezt kívánjuk orvosolni, $s$ velük egy névtani témájú drámagyakorlatokból álló, a későbbiekben online is elérhetővé gyűjteményt szeretnénk megalapozni. A gyakorlatok megalkotásakor több feladatgyüjteményt is használtunk (Ginnis 2007; Kaposi 1993; Raátz 2019; Szajkó 2008). Az egyes gyakorlatok leírásakor a feladat elsődleges célját és használati lehetőségeit, illetve variációit is megadjuk.

Bevezető, ráhangoló feladat lehet akár tanórán, akár egy csoportfoglalkozáson az I. gyakorlat:

\section{I. gyakorlat: Névkör}

A feladat leírása: Álljanak vagy üljenek a tanulók körbe. A tanár/játékvezető egy labdát vagy egy kicsi tárgyat (plüssállatka stb.) kezdjen el valakinek dobni, és indítsa el a feladatot (néhány lehetséges feladatot lásd alább). A labda megy körbe, és a diákok végzik a gyakorlatot mindaddig, amíg le nem állítjuk a játékot. 
a. A kezdő játékos mondja a nevét, majd a következő a saját neve előtt megismétli az elötte elhangzó nevet. A gyakorlat során lehet úgy alakítani a feladatot, hogy mindig csak az utoljára elhangzott utolsó három név kerül megismétlésre (Márta - Kati - Zoli-Juli; Kati-Zoli-Juli-Éva; Zoli-Juli-Éva-Ági). De úgy is történhet a feladat végzése, hogy az elhangzó összes nevet meg kell ismételni. Ez a variáció kisebb létszámú csoportok esetében javasolt.

b. Választhat magának mindenki egy fiktív vagy egy idegen nyelvi nevet, és azt kell a fenti módon a játékban megismételni.

c. A kedvenc városa nevét mondja mindenki.

d. Előre meghatározott tulajdonnévfajtát kell mindenkinek mondania: hegy, utca, tó, tenger, ország, intézmény stb.

e. Egy, a játékvezető által megadott keresztnévhez (pl. Alfonz) kötődő asszociációk mondása, ezek ismétlése. A feladat indítása előtt feltétlenül adjunk példát, beszéljük meg, mit jelent a nevekhez füződő konnotáció, asszociáció!

f. Csak egy adott országhoz, tájegységhez kötődő földrajzi nevek mondása.

A feladat célja: fejleszti az asszociációs készséget, koncentrációt. A feladat alkalmazható ráhangolásként, de bármilyen órán bevezetésként, jól mozgósíthatja a diákok tudását, véleményét.

A készségfejlesztő gyakorlatok közül az alábbiakat javasoljuk:

\section{II. gyakorlat: Ki vagyok? Mi vagyok?}

A feladat leírása: A tanulók hátára egy lapot tüzünk, amelyen egy név, helyesírási szabály stb. van. Senki nem tudja, hogy mi van a hátán lévő lapra írva. A tanulók elkezdenek sétálni a teremben, és megpróbálják egymástól megtudni, hogy mi lehet a hátukon lévő lapra írva. Ennek több módja lehet:

a. Aki leolvassa a társa hátán lévő lapról a szót, annak kell azt úgy elmagyaráznia, körül írnia, hogy a társa kitalálja azt. Magát a szót nem lehet kimondani.

b. A hátán lévő szót, fogalmat mindenkinek úgy kell kitalálnia, hogy a társának, aki látja a szót, kérdéseket tesz föl, és a kérdések alapján kell rájönnie a megoldásra.

Variációk: A játék jól használható a névtani ismertek bövitésére különbözö tantárgyi keretekben. Pl. a gyerekek hátára különbözö tipusú tulajdonneveket irunk. Amikor már mindenki megfejtette a hátán lévö tulajdonnevet, akkor az azonos típusba tartozók (pl. földrajzi nevek, személynevek, csillagnevek) csoportot alkotnak, és a meglévö tulajdonnevek felhasználásával vázlatot, gondolattérképet készitenek az adott tulajdonnévtípusról, vagy szöveget irnak, hiányos szöveget (magyarázó szöveget, verset, szólást, közmondást, vázlatot stb.) kiegészitenek, eljátszanak egy jelenetet úgy, hogy a játékban a tulajdonnevek szerepeljenek. De a meglévö tulajdonnevek felhasználásával felelettervet is irhatnak, amely a szóbeli számonkéréskor használható. 
A feladat célja: az ismeretek rendezése, felidézése. A feladat használható bevezető órán, motivációként, összefoglaláskor, de még számonkéréskor is.

\section{III. gyakorlat: Keressük egymást!}

A feladat leírása: $A z$ előző játék variációja, amikor olyan dolgokat írunk és tüzetünk fel a diákok hátára, amelyek egymással valamilyen módon összefüggésben vannak, pl. egy tulajdonnevet és annak a típusát vagy helyesírási szabályát: Oroszország; földrajzi név, az országneveket mindig egybeírjuk stb. A feladat az, hogy az összetartozók minél hamarabb megtalálják egymást. A diákok szétszórtan mozognak a térben zenére, amikor a zene elhallgat, keresnek valakit, akivel kölcsönösen tájékoztatják egymást - természetesen körülírással -, hogy mi van a másik hátán. Ha valaki gyorsan kitalálja, mi szerepel a hátára tüzött papíron, akkor már célirányosan fogja keresni a társait. Amikor megvan a csoport, akkor készítenek egy gondolattérképet, feleletvázlatot, egy jelenetet, amelyben minden kifejezés szerepel.

A feladat célja: az ismeretek rendezése, felidézése. A feladat használható bevezető órán, motivációként, összefoglaláskor, de még számonkéréskor is.

\section{IV. gyakorlat: Forró szék}

A feladat leírása: Az ismert és gyakran alkalmazott drámás gyakorlatnak az onomasztika területén is többféle felhasználása lehetséges. A forró székbe ültetett személytől a többiek egy meghatározott témában kérdezhetnek. A témák például az alábbiak lehetnek:

a. Az illető mit tud a saját nevéről, annak eredetéről, a szüleinek a névadási motivációjáról?

b. Mi a véleménye a mai névdivatról?

c. Mit tud a nevek kialakulásáról, hogyan választottak, választanak nevet az emberek?

d. Milyen ismeretei vannak a nevek helyesírásról?

e. Lehet, hogy a kérdezők kérdés helyett egy tulajdonnévtípust mondanak, és a székben ülőnek arról kell beszélnie.

f. A székben ülő mond egy tulajdonnevet (pl. Gárdonyi Géza Színház), és a kérdezőknek az intézménynevekkel kapcsolatban kell kérdéseket föltenniük.

A feladat célja: fejleszti a kérdéstechnikát, az egymásra figyelést, illetve a tényanyag ellenőrzésére is jó gyakorlat lehet.

\section{V. gyakorlat: Asszociációk}

A feladat leírása: különböző helyekhez, időhöz kapcsolódó asszociációk, tudás előhívása. A feladat alkalmazható motiváló, bevezető gyakorlatnak.

a. A teremben rajzoljuk föl vagy jelezzük fonallal Magyarország térképét, a két nagy folyót. Kérjük meg a résztvevő diákokat, hogy a vaktérképen álljanak be egy-egy általuk fontos város, domb, folyó, tó helyére. A diákok megnevezik a helyet, majd elmondják, hogy számukra miért fontos, milyen történet kötődik az adott helyhez. 
b. Az előző feladatot úgy is megoldhatjuk, hogy az azonos helyre álló tanulók egymásnak mesélik el történetüket, és az egyéni történetekből közösen alkotnak egy történetet, jelenetet stb.

A feladat célja: asszociációk, a szövegalkotás, az egymásra figyelés fejlesztése.

\section{VI. gyakorlat: Kulcsmondat}

A feladat leírása: Alkossunk csoportokat! Minden csoport húzzon vagy kapjon egy mondatot. A mondat olyan idézet, szólás, közmondás, népi megfigyelés legyen, amelyben szerepel keresztnév.

Pl: Mérges, mint a Gergely-napi idő.

Húzza-vonja, mint Gyurka az ajtót.

Sándor-napja ma vagyon, átbillentem a fagyon.

Ha Dorottya szorítja, Zsuzsanna megtágítja.

Könnyü Katát táncba vinni, ha maga is akarja.

Szűz Mária kötényében sem volna jobb dolga.

A feladat célja: különbözö, a nevekhez kapcsolódó frazeológiai egységek megismerése, azok használata a kommunikációban. Szövegalkotás, kommunikációs készség fejlesztése.

\section{VII. gyakorlat: Fórumszínház}

A feladat leírása: Jelöljünk ki egy, a névadással, névválasztással kapcsolatos helyzetet, erre kérjünk föl szereplőket. Pl. a családban arról döntenek, hogy a hamarosan megszületendő kislány neve mi legyen. Itt a kérdést nyitva is hagyhatjuk, de megadhatunk két nevet, amely közül választani kell (pl. a családnév Kerekes, a két keresztnév: Evelina, Eszter). A család tagjai: apa, anya, tizennégy éves fiú és a nagymama az ebédlőasztalnál ülnek, és beszélgetnek, tanácskoznak. Amíg megy a beszélgetés, közben a játékot kívülről figyelők bármikor föltehetik a kezüket, és megállíthatják a játékot, és instrukciót adhatnak a szereplőknek, hogy hogyan viselkedjenek, például az apa legyen határozottabb, az anya legyen kétségbeesett, a nagyobb fiú legyen közömbös, a nagymama erőszakosabb stb.

Variációk:

a) Egy telefonbeszélgetés során egy anyuka igyekszik meggyőzni azt a nyelvészt, aki a nevek jóváhagyásával foglalkozik, hogy javasolják bejegyzésre a Kócos nevet kisfiúnak.

b) Egy településrész, utca elnevezéséről vitatkoznak a helyi névbizottságban. Adhatunk meg névötleteket is, pl. Malom utca vagy Strasbourg út.

A feladat célja: a vitakultúra, érveléstechnika, kommunikációs készség fejlesztése, a névízlés formálása.

4.2. Gavin Bolton a dramatikus tevékenységek között a tanítási és szakértői drámát is felsorolja (idézi Takács 2008: 32). A tanítási drámáról azt írja Kaposi László (2008: 2), 
hogy ez „a megértés megváltoztatásának szolgálatába állított dráma”. Takács Gábor (2008: 35) megfogalmazása szerint e drámatípusnak „fö célja változás elérése a dráma által kijelölt témában, a vezérfonalként működő fókusz mentén, az alábbi területek valamelyikén: megértési szint, attitűdök, szerepjátékokra vonatkozó elvárások, szociális viselkedés, nyelvi tapasztalatok, empátia. [...] Ez a fajta tevékenység általában megbontja a hagyományos iskolai alá-fölérendeltségi viszonyokat, átrendezheti, megváltoztathatja a hagyományos osztálydinamikai helyzetet". Hangsúlyos a tanár szerepe is: kérdéstechnikájával ugyanis ő biztosíthatja a résztvevők számára a felfedezés örömét, stílusa nyitott (és nem lezáró), nyelvezete felszabadító jellegü, sokszor rejtélyt és talányt sugalló (Takács 2008: 35).

A szakértői dráma a tanítási dráma alkalmazásának komplex, több tanóra alatt, a gyakorlatban általában sorozatok formájában megvalósítható, elsősorban tantárgyi ismeretek átadását, rendszerezését, mélyítését segítő módja (Takács 2008: 35). A tipikus szakértői drámában a résztvevők és a folyamatot irányító tanár egy képzeletbeli, meghatározott célra szerveződo „céget” hoznak létre és kezdenek működtetni. A résztvevők mindvégig a felállított szervezet vagy vállalat munkatársai, szakemberei maradnak. A szakértői játékban a feladatok eszközként szolgálnak, amelyeken keresztül a résztvevők a tanár által kijelölt ismeretterületeket megközelíthetik.

Mivel a tanítási órákon kisebb időigénye miatt elsősorban a tanítási dráma használható (a szakértői drámát fóleg szakkörökön, egyéb nem iskolarendszerü foglalkozásokon érdemes használni), egy névtani témájú tanítási dráma tervét dolgoztuk ki. A mellékletben közölt foglalkozástervünk célja a fontosabb tulajdonnévtípusok bemutatása oly módon, hogy a főbb kategóriákat maguk a diákok alakítják ki.

\section{5. Összegzés}

Tölgyessy Zsuzsanna (2009) így foglalta össze a felnőttek számára tartott drámás foglalkozásainak tapasztalatait: „az átképzésen résztvevő felnőtt csoport szívesebben vett volna részt hasznosabb stúdiumokon: nyelvoktatáson, valuta-pénztárosi képzésen, bármin, ami a munkaerő piacon növelné kompetenciájukat”, illetve „Sokuknak gondot okozott maga a játék, úgy érezték, hogy felnőtt létükkel nem összeegyeztethetö”.

Úgy vélem, a szerzőnek főleg ez utóbbi megjegyzése sokatmondó: a drámás gyakorlatokat és foglalkozásokat sokan érdekes, de kézzelfogható eredményekkel nem járó játékként fogják fel. E vélekedésekkel szembeállíthatók a DICE-projekt 12 ország 111 különböző tanításiszínház- és drámaprogramjában részt vevő csaknem félezer diákjától származó adatának vizsgálati eredményei: a drámapedagógia mérhető, szignifikáns eredményeket adó, hasznos eszköz a kezünkben, mely fóleg a kompetenciák azon területein (a szociális és társas kompetenciák, problémamegoldás, együttműködési készség és empátia) mutat nagy hatékonyságot, ahol a hagyományos módszerek kevésbé hatékonyak. 


\section{Irodalom}

Bacskay Bea - Knausz Imre 2001. Dramatikus módszerek. In: Knausz Imre (szerk.): Azévszámokon innen és túl... Megújuló történelemtanitás. Budapest: Müszaki Könyvkiadó.

DICE - a kocka el van vetve. Kutatási eredmények és ajánlások a tanítási színház és dráma alkalmazásával kapcsolatban. DICE Konzorcium. 2010. http://www.dramanetwork.eu/file/DICE_kutatasi_eredmenyek.pdf (2019.05. 16.)

Eck Júlia 2015. Drámajáték a középiskolai irodalomórán. 2., átdolgozott kiadás. Budapest: Prótea Kulturális Egyesület.

Eck Júlia 2016. A dráma helye a közoktatásban és a tanárképzésben. In: Eck Júlia Kaposi József - Trencsényi László (szerk.): Dráma - pedagógia - szinház - nevelés. Szöveggyüjtemény középhaladóknak. Budapest: Oktatáskutató és Fejlesztő Intézet. 91-113.

Erdélyi Erzsébet 2003. Az új anyanyelv-tanítási módszerek és a hagyományos névtani ismeretek a tantárgyköziség szolgálatában. In. Fercsik Erzsébet (szerk.): $A$ nevekröl. A névtan oktatása és kutatása az ELTE Tanárképzö Föiskolai Kar Magyar Nyelvtudományi Tanszékén 1984-2003. Budapest: Krónika Nova Kiadó. 204-226.

Fábián Györgyi - Singer Péter 2009. Az anyanyelv és kommunikáció tanítása az iskolarendszerü felnőttoktatásban. Új Pedagógiai Szemle. http://ofi.hu/dr-fabian-gyorgyisinger-peter-az-anyanyelv-es-kommunikacio-tanitasa-az-iskolarendszeru (2019. 05. 16.)

Fercsik Erzsébet 1999. Nem lehet elég korán kezdeni - Névtani ismeretek egy anyanyelvi tankönyvcsaládban. Névtani Értesítő 21: 310-314.

Fercsik Erzsébet - Raátz Judit 1995. Névtani foglalkozások I. Magyartanitás 5: 41-47.

Fercsik Erzsébet - Raátz Judit 1996. Névtani foglalkozások II. Magyartanitás 1: 34-39.

Fercsik Erzsébet 2014. Keresztnevek. Munkafüzet a Tinta Könyvkiadó Keresztnevek enciklopédiája címü kiadványához. Anyanyelvi Kompetenciafejlesztő Munkafüzetek 3. Budapest: Tinta Könyvkiadó.

Gabnai Katalin 2008. Drámajátékok. Bevezetés a drámapedagógiába. 4., bővített kiadás változatlan utánnyomása. Budapest: Helikon Kiadó.

Gelegonyáné Katona Ágnes 2015. Gimnazisták névtani tájékozottsága. Anyanyelvpedagógia 8/3. http://www.anyanyelv-pedagogia.hu/cikkek.php?id=582 (2019. 05. 19.)

Ginnis, Paul 2007. Tanitási és tanulási receptkönyv. Pécs: Alexandra Kiadó.

Hoffmann Ottó 1994. Kalandozások a nevek birodalmában. Magyartanítás 4: 27-30.

Kaposi Lászó (szerk.) 1993. Játékkönyv. Budapest: Marczibányi Téri Művelődési Központ Kerekasztal Színházi Nevelési Központ.

Kaposi László 2008. Mi a dráma és mi nem az? Dráma és színház. In: Lipták Ildikó (szerk.): Tanitási dráma - Drámapedagógia a hátrányos helyzetü tanulók integrált nevelésének elösegitésére. Budapest: Educatio Társadalmi Szolgáltató Közhasznú Társaság. 2-6. 
Kecskés Judit 2018. Névtudományi ismeretek az újgenerációs, 5-12. osztályos Magyar nyelv tankönyvekben. Az újratervezés lehetőségei a Nemzeti alaptanterv tervezete tükrében. Névtani Értesito" 40: 13-27. https://doi.org/10.29178/NevtErt.2018.1

Láncz Éva 2016. Névtudományi ismeretek a magyar nyelvi órán. Anyanyelv-pedagógia 9/4: 47-61. http://www.anyanyelv-pedagogia.hu/cikkek.php?id=653 (2019. 05. 16.) https://doi.org/10.21030/anyp.2016.4.4

Liszka Gábor 1997. A névtan a nyolcosztályos gimnáziumokban. In: B. Gergely Piroska - Hajdú Mihály (szerk.): Az V. Magyar Névtudományi Konferencia elöadásai. Budapest: A Magyar Nyelvtudományi Társaság Kiadványai 209. 513-518.

Novák Géza Máté 2016. Dráma és pedagógia. A drámapedagógia aktuális kérdéseiről. Neveléstudomány 4/2: 43-52. https://doi.org/10.21549/NTNY.14.2016.2.3

Pándiné Csajági Mária 2017. Szabad a játék. Legyen élmény a tanulás játékos módszerekkel! Budapest: Neteducatio Kft.

Raátz Judit 1994. Az általános iskolai tanulók névtani ismeretei egy felmérés tükrében. Magyartanitás 5: 29-33.

Raátz Judit 2003. A névtan szerepe és helye az anyanyelvi nevelésben. In: Katona András - Szombatiné Kovács Margit - Ládi László - Széplaki György (szerk.): A tanári mesterség gyakorlata. Tanárképzés és tudomány. Budapest: Nemzeti Tankönyvkiadó ELTE Tanárképző Főiskolai Kar. 239-245.

Raátz Judit 2015. A kommunikációs kompetencia területei és fejlesztési lehetőségei az anyanyelvi nevelésben. In: Antalné Szabó Ágnes - Laczkó Krisztina - Raátz Judit (szerk.): Szakpedagógiai körkép I. Anyanyelv-és irodalompedagógiai tanulmányok. Budapest: Eötvös Loránd Tudományegyetem. 71-93.

Raátz Judit 2019. A tanulói kommunikáció fejlesztése drámapedagógiával. In: Terbe Erika (szerk.): A tanulástámogató kommunikáció fejlesztése. Budapest: Eötvös Loránd Tudományegyetem. 68-91.

Spencer, Lyle M. - McClelland, David C. - Spencer, Signe M. 1994. Competency assessment methods: History and state of art. London: Hay/McBer Research Press. 3-44.

Szajkó Ottília 2008. A drámajáték lehetséges alkalmazási területei a történelemórán. Tani-tani Online 4: 83-91. http://www.tani-tani.info/084szajko (2019. 05. 16.)

Szauder Erik (szerk.) 1994. Dráma - Oktatás - Nevelés. Olvasókönyv a dráma pedagógiai alkalmazásához. Budapest: Nemzeti Tankönyvkiadó.

Szauder Erik 1996. A dráma mint pedagógia I. Drámapedagógiai Magazin 2: 10-16.

Szőke-Milinte Enikő 2012. A kommunikációs kompetencia a 2012-es NAT vitaanyagában. Anyanyelv-pedagógia 5/2. http://www.anyanyelv-pedagogia.hu/cikkek. php?id=380 (2019. 05. 16.)

Takács Gábor 2008. A dramatikus tevékenység rendszerezése. In: Lipták Ildikó (szerk.): Tanitási dráma - Drámapedagógia a hátrányos helyzetü tanulók integrált nevelésének elösegitésére. Budapest: Educatio Társadalmi Szolgáltató Közhasznú Társaság. 32-37. 
H. Tomesz Tímea 2018. Kommunikációs készségfejlesztés kisiskolás korban. In: H. Varga Gyula (szerk.): Kommunikációs tudatosság - Médiatudatosság. Budapest: Hungarovox Kiadó. 1-14.

Tölgyessy Zsuzsanna 2009. Mi is az a drámapedagógia? Tani-tani Online 4: 36-39. http://www.tani-tani.info/094_tolgyessy (2019.05. 16.)

Varga Irén - Gönczi Károly - Pintér István 2004. Önismereti játékok gyüjteménye.

Tanári kézikönyv. Debrecen: Pedellus Tankönyvkiadó.

Vörös Ferenc 2015. Miként hasznosíthatók a Névtani Értesítő tanulmányai a magyartanításban? Anyanyelv-pedagógia 8/3. http://www.anyanyelv-pedagogia.hu/cikkek. php?id=585 (2019. 05. 16.)

Zántó Edina 2018. Hogyan használható egy névtani kötet a középiskolai tanításban? Farkas Tamás - Slíz Mariann (szerk.): Magyar névkutatás a 21. század elején. Hajdú Mihály emlékére. Anyanyelv-pedagógia 11/1: 64-70.

https://doi.org/10.21030/anyp.2018.1.6

\section{Melléklet}

\section{Tanítási dráma foglalkozásterv}

Csoport: 10-14 éves korosztály

Létszám: 30 fô" (ideális létszám: 15-20 fö)

Tér: osztályterem

Időtartam: 90 perc

Kellékek, eszközök: csomagoló papír, A/4-es lapok, filcek, tollak, blue tack, kalap

Tanulási terület: A névtan, a tulajdonnévtípusok megismerése. Személyiségfejlesztés és közösségépítés.

Cél: A tulajdonnévtípusok felismerése, névszociológiához kapcsolódó ismeretek átadása.

Fókusz: Mi az, ami nélkül nem tudunk élni egy városban? A város legfőbb terei, intézményei.

Történetváz, keret: Egyetlen lakosa van már csak az ország eldugott zugában lévő a kisvárosnak, a polgármester (= tanár) fiatal betelepülőket toboroz, hogy a lakatlan épületekből álló területeken igényeiknek megfelelően újraépítsék a várost. A betelepülők (a diákok, azaz a városlakók) feladata lesz a város, és minden benne lévő dolog (tárgy, épület, intézmény, üzlet) kitalálása, elrendezése, elnevezése.

\section{Tanári narráció, közös beszélgetés}

A tanár körbeülteti a diákokat, és arról beszélget velük, milyen városban szeretnének lakni, mi az, ami nélkül nem tudnának élni, milyen vágyaik, elképzeléseik vannak 
az ideális lakóhellyel kapcsolatban.

\section{A tanár szerepben-polgármesterként}

A tanár a polgármester szerepét ölti magára, s ezt egy kalappal érzékelteti. Az egész foglalkozás során a kalap lesz a tárgyi jelzése a pedagógusnak arra, ha szerepet vált. A polgármester köszönti az érdeklődőket, akik a felhívására szeretnének a város új lakói lenni. Ismerteti velük, hogy azért toborzott embereket, mert már csak egyedül él a kisvárosban, $s$ az adottságokat, lehetőségeket kihasználva szeretné, ha újraépítenék a várost, mielőtt végleg kihalna, megsemmisülne.

\section{3. Állókép}

A tanár azt kéri a tanulóktól, hogy készítsenek egy olyan állóképet, amely jelzi, hogy kik ők a városban!

\section{Belsö hang}

A pedagógus az elkészített állókép tagjainak egyesével megérinti a vállát, $s$ a következő kérdéseket intézi feléjük: hogy hívnak, ki vagy?

\section{Gyülés}

A tanár polgármester szerepében gyủlést hív össze, hogy a városlakók megvitassák, pontosan mire is van szükségük a városban (intézmény, üzlet stb.). Arra kéri őket, hogy az elfogadott ötleteket papíron rögzítsék, s emellett azt is gyüjtsék össze, hogy mire van szükség az ötlet megvalósításához. A diákok a városlakók, akik az előző állókép és belső hang konvencióval nevet és szerepet választottak maguknak, ebben a szerepben dolgoznak.

6. Tanári narráció, amelyből kiderül, hogy 1 hónap telt el a gyűlés óta, s a városlakók jelenlegi életébe fogunk bepillantást nyerni.

7. Csoportos improvizáció a kisváros egy napjáról: 5 csoportot alkotunk, s mindegyik a város egy napjának különböző időszakát (reggel, délelőtt, dél, délután, este) mutatja be. Rövid egyeztetés után a csoportok elkezdik játszani, bemutatni ezeket a helyzeteket, életképeket.

\section{Gyülés}

A tanár a polgármester szerepében újból gyülést hív össze, hogy a korábbi alkalommal kitalált ötleteket véglegesítsék, s készítsenek részletes térképet a városról, amelyen minden létesítmény és annak neve is szerepel. Közösen megrajzoljuk a várost, $s$ mindent elrendezünk és elnevezünk rajta. Az elkészült térképet a névbizottság fogja értékelni és jóvá hagyni. 
A tanár a polgármester szerepében azt kéri a lakóktól, hogy mindenki egy mondatban foglalja össze a kívánságát, hogy mit vár az ő általa tervezett területen. Azzal zárja a gyưlést és az egész foglalkozást, hogy sikerült elkészíteni a térképet, így befejeződött a munkájuk. A térképvázlatot továbbítani fogja értékelésre a névbizottságnak, és végül megköszöni a városlakók kitartó, odaadó munkáját.

Az elkészült térképen szereplő tulajdonneveket a későbbi órákon akár a szófajtan, akár a szófajok helyesírásának tanításakor föl lehet használni.

A foglalkozáshoz kapcsolódó további feladat lehet, hogy a képzeletbeli városlakók elkészítik a saját profiljukat valamelyik közösségi médiumra. Ezen a nevük, születési helyük, lakhelyük, iskoláik, munkahelyük, családtagjaik, kedvenc állataik neve is szerepeljen. 